\title{
ПСЕВДОВИРУСНЫЕ СИСТЕМЫ ДЛЯ ПОИСКА ПРОТИВОВИРУСНЫХ СРЕДСТВ
}

\author{
А.А. Кононова, С.В. Чересиз, А.Г. Покровский 1 \\ Лаборатория фундаментальной медицины, Новосибирский Государственный \\ Университет, 630090, РФ, г. Новосибирск, ул. Пирогова, д. 1.
}

DOI: 10.19163/MedChemRussia2021-2021-211

E-mail: alenkononova@yandex.ru

Экспериментальные работы, направленные на поиск противовирусных средств, действующих в отношении высокопатогенных вирусов, требуют соблюдения целого ряда строгих правил, направленных на обеспечение личной и общественной безопасности и защиту окружающей среды. Для соблюдения этих требований необходима специальная подготовка сотрудников, а также особые материальные и инженерно-технические условия, доступные лишь ограниченному числу лабораторий. Биологически безопасные модельные тест-системы позволяют более широкому кругу исследователей производить поиск потенциальных противовирусных агентов.

Псевдовирусы - репликационно-дефектные химерные частицы, содержащие капсидные белки одного вируса и поверхностные белки другого, воспроизводят отдельные этапы жизненного цикла инфекционных вирусов и могут быть использованы для поиска противовирусных агентов. Важным преимуществом использования псевдовирусов является возможность изучения отдельных стадий вирусной инфекции, обусловленных конкретными белками (в том числе, поверхностными белками, ответственными за начальные стадии инфекции), что бывает важно для четкого определения молекулярной мишени противовирусного соединения.

Нами получена коллекция псевдовирусов на основе капсида рекомбинантного вируса везикулярного стоматита, а также на основе лентивирусного капсида, для поиска ингибиторов поверхностных белков филовирусов (вирус Марбург), вируса гриппа A (субтип H5N1), нового коронавируса SARS-CoV-2 и найдены соединения, селективно и неселективно блокирующие данные псевдовирусы.

Использование псевдовирусов позволяет оптимизировать процедуру поиска и изучения эффективных антивирусных препаратов, дает возможность оценивать эффективность кандидатных препаратов до начала их тестирования с помощью инфекционных вирусных изолятов, или же изучать механизмы действия веществ с уже выявленной противовирусной активностью. 